\title{
UP TO HERE IN LAOS
}

VOLUME 13, No.3

March 1970

WORLDVIEW is published monthly [except for a combined July-August issue] by the Council on Religion and International Af. fairs. Subscription $\$ 4.00$ for one year; $\$ 7.00$ for two years; $\$ 9.00$ for three years.

Address: 170 East 64th Street, New York, New York 10021. TE 8-4120

\section{EDITORIAL BOARD \\ James Finn: Editor \\ John R. Inman \\ A. William Loos \\ Editorial Assistants: \\ Susan Woolfson \\ Kip Zegers}

Contributing Editors: Donald Brandon, Jerald C. Brauer, Ernest W. Lefever, Bernard Murchland, Edmund Stilman

\section{CONTENTS}

$\begin{array}{lr}\text { In the Magazines } & 2 \\ \text { Up to Here in Laos } & 3 \\ \text { Technical Expert, Confused Moralist } & 4 \\ \begin{array}{l}\text { Genocide } \\ \text { Editorials }\end{array} & 4 \\ \text { The Global Democrat: Morality for } \\ \text { the Postnational Age } \\ \text { Thomas J. Knight } \\ \begin{array}{l}\text { This Year in Jerusalem } \\ \text { Arthtif J. Moore, Jr. }\end{array} \\ \begin{array}{l}\text { A Review of Events in Laos } \\ \text { The Press }\end{array} \\ \begin{array}{l}\text { Toward "Understanding" Modern } \\ \text { China } \\ \text { Harold C. Hinton }\end{array}\end{array}$

Readers aro reminded that worldyiow welcomes correxpondence. Letters may be speciflc com ments on sirticles in recent fanves of penersi diccupolon, but readers ane requasted to limit thair fotters to 500 words.

Oplniovis exprossed in worldriew the those of the zuthors, and not necessarily of the Council on 1970 Council on Religion and international Aftalrs,
It has, as an issue, been with us for years. But for only a few people las it been a lively issue of continuous interest. For most of us Laios has been screened lychind veils of indifference which were only occistomally piereed by somm enlightening bits of information. We knew, of course, that it was neat to Vietnam; that sulstantial Viot Comg supplies passed down the Ho Chi Minh trail which winds through Laos; that if the familiar domino theory trad validity I aoss miglit be the next domino. The news from and about Viet. nam, lowerer, dominated both the media and our own thinking.

The rumning press accounts which appear elsewhere in this issuc siggest the hind and amonnt of information $t o$ which the pulblic had access until the end of Felruary, 1970. Now - ahnost dramatically - the situation hiss changed. The President of the United States is called upon to review the history of United States policy and action in l alos. And almost immediately his credibility om Iass is, howner tangentially. called into question.

In his generally historical, even-toned review of I ans. President Nison proposed very modest oljectives for United States military policy in Laos. We are there, lie said, to "sate" American and allied lives in North Vietnim which are threatcucd by the continual infiltation of $\mathrm{North} V \mathrm{~V}$ intmamese troops and supplies alomg the Ho Chi Minl trail." There wis, in his statement, nothing to sugesest that Lates itself wats of vital interest to the Linited States, no mention of binding agrements, no stress on moral and political obligations. Both in tenor and substance President Nixon's comments were a far remove from the perfervid statements with which past Administrations explained and justified United States policies and actions in Vietnam. So much, at liast, we have learned over the last mumber of years. And the l'resident's effort to statbilize the situation in Laus in accorlance with the Geneva Conference of 1962 and with the support of the Soviet Union and Britain is, of course, both proper and desirahle.

We must admit, however, that the prollems of Laos ciumnot he wholly separated from thesse of Victnam: they are as closely related in terms of United States forejgn policy as the two colintries are geographically. And there are a host of difficult and pressing guestions to which we mosst respond. The Pathet Lao, for eximple, has demanded that the U.S. withdraw from Lios and that there be established in new coalition stoverntment dominated by the Pathet Lao. Familiar? Indeed it is. It is the kind of demand Washington has received and rejected in Vietnam for many ycars. Other problems posed to the United States also have a fatniliar cast.

For example: if the North Vietnanese increase their forces in Ians, how should the United States respond? If with

March 1970 : 
further military victories to their credit, the Pathet Lao spurn any suggestions from Russia (the likelihood of such suggestions already highly dibious) or from England that an acceptable solution can best be pursued through diplomatic channels, what then should the United States do? If more Americans, civilian or military, are killed by enemy action in Laos, what then should the United States do? If the problems of United States policy in Laos are exacerbated in order to bring pressure on our actions in Vietnam, what then should the United States do?

Reduced to the essentials we can ask ahout the present situation and future actions in Laos: How far are we in? Not much, as President Nixon implies? Or "up to our neck," as Senator Mansfield asserts? How committed are we to our present policy and its likely consequences? Can we have, beforehand, the kind of review of U.S. involvement and commitment in Lans that we so badly needed and never received about Vietnam?

\section{TECHNICAL EXPERT, CONFUSED MORALIST}

Dr. James B. Conant has been justly honored for his achievements in many fields--scientific, political and educational. But in his recent autobiography he enters into questions of morality and war with an abandon that does little to clarify what are still very murky matters.

Dr. Conant not only defends dropping the atomic bomb on Japan, but he rejects any distinction between the use of high explosives and poison gas in warfare. He has, admittedly, a number of respected spokesmen on his side. Nevertheless, his argument should be challenged and exposed for the skimpy, unattractive and unacceptable thing it is.

The basis of Dr. Conant's moral-military judg. ment rests on a single premise, i.e., "All war is immoral." This too is a familiar statement which is supported by a large, and possibly increasing, number of people. It may at first blush seem like an odd statement to issue from a person who contributed so much to America's atomic weapons in World War II and who still defends the most extreme application of those weapons. But as Dr. Conant offers his judgment the apparent dilemma is resolved.
"All war is immoral," James Conant asserts. Since it is immoral, his other statements imply, it is foolish to make moral discriminations about the means. The atomic bombs dropped on Japan and possible poison gases are, therefore, as legitimate weapons as any others. And with this line of reasoning Dr. Conant has established himself in a long American tradition of thinking about warfare. We are a peace-loving people and do not wish to engage in war, but since war is immoral, once we enter let there be no constraints, 110 moral inhibitions.

Although it is a long tradition, and although it will continue to gain adherents as intelligent and knowledgeable as Dr. Conant, it is, nonetheless, a morally bankrupt tradition. And it is morally bankrupt because it is, in the first instance, intellectually bankrupt. It does not allow us to answer basic and perennial questions about communities in conflict.

If for example, we or allied countries are unjustly attacked, is it immoral for us to defend ourselves or them? And by any means? If we are an oppressed colonial people, can we not attempt to gain our freedom by violently rebelling against our rulers? If, as a nation, we attempt to aggrandize ourselves through military conquests, are our actions not subject to moral judgment? These are not simply abstract questions. Each of the foregoing questions could be applied to the United States during some period of its development. They are questions which, unfortunately, will retain their pertinence for years to come. But we must look elsewhere than to James Conant if we are to answer them.

\section{GENOCIDE}

There are no reasons for the United States to postpone ratification of the International Convention on Genocide. That is, there are no good reasons. On the basis of bad reasons and spurious argument, the American Bar Association and some Southern Senators have blocked Senate ratification since 1950. As the Catholic hierarchy of the United States stated in "Human Life in Our Day": "We would urge United States ratification of the United Nations convention on the subject [genocide] and of every sound implementing instrument by which the United Nations Declaration on Hiuman Rights can be translated from the level of ideals to that of actuality." 